\title{
Distorsi citra tubuh, perilaku makan, dan fad diets pada remaja putri di Yogyakarta
}

Body image distortion, eating behavior, and fad diets among female adolescents in Yogyakarta

\author{
Atika Sulistyan ${ }^{1}$, Emy Huryati ${ }^{1}$, Janatin Hastuti ${ }^{2}$ \\ 'Departemen Gizi Kesehatan, Fakultas Kedokteran Universitas Gadjah Mada \\ ${ }^{2}$ Laboratorium Bioantropologi \& Paleoantropologi, Fakultas Kedokteran Universitas Gadjah Mada
}

\begin{abstract}
Background: Vast changing environment and culture including mass media which commonly shows models with a very slim body may cause teenage girls feel fatty and not confident despite their normal body weight. This misperception may influence eating behaviour and encourage them to lose weight by involving in some instant diets, for example fad diets. Objective: To identify relationships between body image distortion, eating behaviour, and fad diets among female adolescents in Yogyakarta. Method: This study was a cross-sectional study on 123 school girls at SMAN 8 Yogyakarta who have normal body mass index (BMI) according to WHO category. Body image distortion and eating behaviour were evaluated using the Body Image Assesment-Body Dimension (BIAS-BD), and the Eating Attitude Test (EAT)-26, respectively. Fad diets was assessed using a questionnaire adopted from Hana (10) and Rafiqa (11). The hypotheses were tested using chi-square test and Spearman's corelations. Results: As many as 105 girls (85.4\%) showed body image distortion and 15 girls (12.2\%) were at risks for having disordered eating behaviour. Among 51 girls (42.5\%) who experienced or tried to loose weight, 47 girls (92.2\%) were practicing fad diets. There was no significant association between body image distortion and disordered eating behaviour, nor between body image distortion and fad diets. However, disordered eating behaviour was significantly associated with fad diets with $O R=7,077(p<0.05)$. Conclusion: There was a significant relationship $(p<0.05)$ between disordered eating behaviour and fad diets, however, no significant association was found between body image distortion and disoredered eating behaviour, and between body image distortion and fad diets among female adolescents in Yogyakarta.
\end{abstract}

KEY WORDS: body image distortion; body mass index; eating behavior; fad diets; female high school students

\begin{abstract}
ABSTRAK
Latar belakang: Perubahan lingkungan dan budaya yang pesat termasuk media massa yang biasanya menampilkan model dengan tubuh sangat kurus dapat mempengaruhi remaja putri menjadi merasa dirinya gemuk meskipun ukuran tubuh termasuk normal. Persepsi ini dapat mempengaruhi perilaku makan dan memicu keinginan untuk menurunkan berat badan secara instan, misalnya dengan fad diets. Tujuan: Mengetahui hubungan antara distorsi citra tubuh, perilaku makan, dan fad diets pada remaja putri di Yogyakarta dengan indeks massa tubuh (IMT) normal. Metode: Desain penelitian berupa cross-sectional dengan sampel siswi kelas X-XII yang memiliki IMT normal menurut WHO di SMAN 8 Yogyakarta. Responden diambil menggunakan metode cluster sampling dengan total 123 responden. Variabel distorsi citra tubuh diukur dengan menggunakan body image assesment-body dimension (BIAS-BD), perilaku makan menggunakan kuesioner eating attitude test (EAT)-26, dan fad diets menggunakan kuesioner yang diadaptasi dari penelitian sebelumnya. Uji hipotesis yang digunakan adalah uji Chi-Square dan korelasi Spearman. Hasil: Diketahui 105 responden (85,4\%) memiliki distorsi citra tubuh dan 15 responden (12,2\%) berisiko tinggi untuk terlibat dalam gangguan perilaku makan. Sejumlah 51 responden (42,5\%) sedang atau pernah mengupayakan penurunan berat badan dan 47 orang $(92,2 \%)$ diantaranya mengupayakan penurunan berat badan dengan metode fad diets. Tidak terdapat hubungan signifikan antara distorsi citra tubuh dengan gangguan perilaku makan, demikian juga dengan hubungan antara distorsi citra tubuh dengan fad diets. Namun, ditemukan hubungan antara gangguan perilaku makan dengan fad diets $(\mathrm{p}<0,01 ; \mathrm{OR}=7,077)$. Simpulan: Terdapat hubungan signifikan antara gangguan perilaku makan dengan fad diets, tetapi tidak ditemukan hubungan yang signifikan antara distorsi citra tubuh dengan fad diets serta distorsi citra tubuh dengan gangguan perilaku makan pada remaja putri di Yogyakarta dengan IMT normal.
\end{abstract}

KATA KUNCI: distorsi citra tubuh; indeks massa tubuh; perilaku makan; fad diets; siswi SMA

Korespondensi: Janatin Hastuti, Laboratorium Bioantropologi \& Paleoantropologi, Fakultas Kedokteran Universitas Gadjah Mada. Jl. Medika, Sekip, Sleman, Yogyakarta 55281, Telp: 0274-552577, Fax: 0274-552577, e-mail: janatin.hastuti@ugm.ac.id 


\section{PENDAHULUAN}

Remaja putri lebih banyak menaruh perhatian tentang penampilan fisik mereka dibandingkan dengan remaja pria, bahkan sejak usia yang sangat dini yaitu 4 tahun (1). Selain jenis kelamin dan umur, facktor lingkungan, budaya, kepribadian, keluarga, dan media massa turut mempengaruhi citra tubuh (2). Media massa mempengaruhi citra tubuh melalui proses persepsi, afektif, kognitif dan perilaku $(3,4)$. Paparan media massa dapat berpengaruh negative terhadap citra tubuh dan kondisi psikologis individual (5). Remaja putri seringkali membandingkan bentuk tubuhnya dengan bentuk tubuh teman-temannya serta sangat mudah terpengaruh oleh bentuk tubuh para model yang mereka lihat di media (6). Permasalahannya adalah bentuk tubuh yang dilihat para remaja tersebut tidak selalu merupakan gambaran dari tubuh yang memiliki status gizi normal. Nilai rata-rata indeks massa tubuh (IMT) para model yang ditampilkan di media massa bernilai jauh di bawah IMT normal dan dapat dikategorikan sebagai bentuk tubuh yang sangat kurus (7). Hal ini menyebabkan remaja mengira bahwa tubuh yang ideal adalah tubuh yang kurus sehingga membuat mereka berupaya untuk menurunkan berat badan.

Saat ini, diet tidak hanya dilakukan oleh remaja putri yang gemuk dan memang perlu menurunkan berat badan. Remaja dengan berat badan normal pun sering merasa dirinya terlalu gemuk dan ingin menurunkan berat badannya untuk mencapai tubuh "ideal" yang dicitrakan oleh media massa $(6,8,9)$. Selain media massa, keinginan untuk menurunkan berat badan pada remaja putri juga dipengaruhi oleh teman bermain dan anggota keluarga yang sudah dewasa $(10,11)$. Berdasarkan beberapa penelitian, sebagian besar remaja putri merasa tidak puas dengan bentuk tubuhnya meskipun IMT mereka termasuk ideal atau kurus (1214). Ketidaksesuaian citra tubuh terhadap ukuran, proporsi, maupun bentuk tubuh ini disebut dengan distorsi citra tubuh. Menurut Families Empowered and Supporting Treatment of Eating Disorder (FEAST), distorsi citra tubuh merupakan ketidaksesuaian antara ukuran tubuh yang sesungguhnya dengan ukuran tubuh yang dipersepsikan oleh seseorang dengan distorsi citra tubuh.
Distorsi citra tubuh pada remaja berhubungan erat dengan perilaku makan. Remaja putri dengan distorsi citra tubuh akan memiliki risiko lebih tinggi untuk terlibat dalam perilaku makan yang menyimpang seperti anoreksia dan bulimia nervosa (15). Gangguan perilaku makan yang dialami remaja berkaitan dengan jenis upaya penurunan berat badan yang dilakukan. Diet yang dilakukan para remaja ini kebanyakan adalah diet tidak sehat yang sering disebut juga dengan fad diets. The American Dietetic Association mendefinisikan fad diets sebagai diet yang menjanjikan penurunan berat badan secara instan tanpa harus berolahraga namun tidak didasari oleh dasar ilmiah yang jelas. Penelitian terhadap 75 siswi SMA Negeri 6 di Kota Yogyakarta yang diketahui sedang menjalankan diet menunjukkan bahwa mereka menggunakan metode fad diets $(16,17)$. Jenis diet tidak aman ini dapat menimbulkan risiko berbagai gangguan kesehatan seperti ketosis, gangguan keseimbangan cairan dan elektrolit, hingga menyebabkan kerusakan ginjal (18).

Kebanyakan studi terkait distorsi citra tubuh, perilaku makan, dan fad diets mengambil sampel yang berasal dari semua status gizi, baik gemuk, normal maupun kurus $(8,19-23)$ dan belum banyak penelitian yang secara khusus mengkaji faktor-faktor tersebut hanya pada kelompok remaja dengan status gizi normal. Di Indonesia, meskipun angka remaja putri yang terlibat maupun yang berisiko terlibat dalam perilaku fad diets termasuk tinggi $(14,16,17,24)$, jumlah penelitian yang mengkaji faktor-faktor yang berkaitan dengan perilaku tersebut masih sedikit. Perilaku makan tidak sehat dapat menimbulkan komplikasi kesehatan yang buruk, meliputi penyakit-penyakit mayor seperti penyakit kardiovaskuler, sindrom metabolik, dan kelainan gastrointestinum (25). Sementara itu, semakin besar distorsi citra tubuh, dapat menyebabkan gangguan perilaku makan menjadi lebih parah serta faktor risiko kelainan perilaku makan seperti anoreksia nervosa dan bulimia nervosa (20-24).

Berdasarkan penjelasan tersebut, penting untuk dilakukan penelitian yang bertujuan untuk mengetahui adakah hubungan antara distorsi citra tubuh, perilaku makan, dan fad diets pada remaja putri. Dengan demikian, penelitian ini bertujuan untuk melihat adanya hubungan antara ketiga variabel tersebut pada remaja putri di Yogyakarta yang memiliki IMT normal. 


\section{BAHAN DAN METODE}

Penelitian ini merupakan studi cross-sectional yang dilakukan pada bulan Oktober 2015 dan berlokasi di SMAN 8 Yogyakarta. Populasi penelitian adalah seluruh siswi SMA Negeri 8 Yogyakarta yang memiliki IMT dalam rentang $-2 \mathrm{SD}$ hingga $+1 \mathrm{SD}$ menurut standar IMT/U pada anak perempuan usia 5-19 tahun (26). Kriteria inklusi pada penelitian ini antara lain berstatus aktif sebagai siswi di kelas X-XII pada SMAN 8 Yogyakarta, memiliki IMT normal, dan bersedia mengikuti jalannya penelitian hingga selesai. Sementara itu, kriteria eksklusi yaitu subjek yang sedang menderita sakit atau menjalani diet khusus karena penyakit tertentu. Penelitian ini telah mendapat persetujuan etik dari Komisi Etik Penelitian Kedokteran dan Kesehatan Fakultas Kedokteran Universitas Gadjah Mada.

Perhitungan jumlah sampel didasarkan pada proporsi remaja putri yang melakukan fad diets sebesar 26,4\% (10-11); limit error (d) sebesar 0,1; dan derajat kepercayaan sebesar 0,05 $(\alpha)$. Berdasarkan rumus perhitungan sampel (27) didapatkan sampel minimal sebesar 75 responden. Pengambilan sampel menggunakan metode cluster sampling untuk menentukan kelas yang terpilih untuk mewakili populasi dari setiap tingkat. Total jumlah klaster (kelas) yang ada (kelas X-XII) adalah 25, dengan jumlah siswi perempuan masing-masing tingkat yaitu 180, 180, dan 133 siswi. Kelas terpilih diambil secara random, meliputi kelas X (3 kelas) dengan jumlah sampel 55, kelas XI (3 kelas) dengan jumlah sampel 45, dan kelas XII (4 kelas) dengan jumlah sampel 38 siswi. Skrining dilakukan terhadap seluruh siswi kelas terpilih. Pada tahap skrining menurut IMT, jumlah responden yang memenuhi kriteria didapatkan sebanyak 138 responden, tetapi terdapat 15 responden yang tidak mengisi kuesioner dengan lengkap dan dinyatakan drop out sehingga jumlah akhir responden adalah sebanyak 123 responden.

Variabel bebas pada penelitian ini adalah distorsi citra tubuh sedangkan variabel terikat meliputi perilaku makan dan fad diets. Distorsi citra tubuh diukur dengan Body Image Assesment-Body Dimension (BIAS-BD) yang dikembangkan oleh Gardner et al. (28). BIAS-BD membandingkan nilai figur yang dipilih oleh partisipan sebagai figur yang mewakili bentuk tubuhnya dengan nilai figur sesungguhnya berdasarkan tabel IMT.
Perbedaan figur antara yang dipilih partisipan dan figur menurut IMT menunjukkan adanya distorsi. Kuesioner ini telah melalui tahap uji validitas dan reabilitas dengan kuesioner pembanding Figure Rating Scale (FRS) (29) terhadap siswi SMA di kota Yogyakarta. Hasil perbandingan dengan FRS dari segi kelompok status gizi, nilai reliabilitas BIAS-BD adalah 0,823 dan nilai validitas sebesar 0,667 . Sementara itu, jika dilihat dari segi pemilihan gambar yang tertera pada kedua kuesioner, nilai reliabilitas BIAS-BD adalah 0,811 dan nilai validitasnya sebesar 0,796 .

Risiko gangguan perilaku makan seseorang diukur dengan kuesioner Eating Attitude Test (EAT) yang dikembangkan dari penelitian sebelumnya (30) yang berisi 26 item pertanyaan yang telah diterjemahkan ke dalam bahasa Indonesia dan diadaptasi dari penelitian Rahayu (24). Rentang nilai pada setiap pertanyaan yaitu 0-3 (tidak pernah, jarang, kadang $=0$; sering $=$ 1 ; hampir selalu $=2$; selalu $=3$ ). Hasil skor lebih dari atau sama dengan 20 menunjukkan adanya risiko tinggi gangguan perilaku makan. Kuesioner terjemahan EAT-26 telah melewati uji validitas dan reliabilitas dengan nilai reliabilitas 0,907 dan validitas 0,361.

Sementara itu, untuk mengetahui apakah upaya penurunan berat badan yang dilakukan responden termasuk fad diets, dilakukan pengukuran dengan menggunakan kuesioner yang telah disusun dalam penelitian sebelumnya (16,17). Kuesioner ini berisi 9 pertanyaan dengan pilihan jawaban ya (skor $=1$ ) dan tidak (skor=0) yang mengacu pada American Dietetic Association dan British Dietetic Association. Fad diets dibuktikan dengan nilai minimal 1. Berdasarkan uji validasi terdahulu, koefisien validitas setiap item pertanyaan sudah di atas 0,3 dan nilai reliabilitas kuesioner fad diets adalah 0,756.

Uji univariat dilakukan untuk mengetahui karakteristik responden dan prevalensi distribusi masing-masing variabel sedangkan hubungan antara variabel bebas dan terikat diketahui dengan melakukan uji Chi-Square dengan derajat kepercayaan 95\%. Variabel yang diuji hubungannya adalah distorsi citra tubuh dan fad diets, perilaku makan, dan fad diets serta distorsi citra tubuh dengan perilaku makan dengan uji korelasi Spearman. 
Tabel 1. Karakteristik responden $(n=123)$

\begin{tabular}{lccc}
\hline Variabel & Minimum & Maksimum & Rerata \pm SD \\
\hline Usia (tahun) & 14,9 & 18,2 & $16,5 \pm 0,9$ \\
Berat badan $(\mathrm{kg})$ & 34,9 & 66,6 & $49,4 \pm 5,9$ \\
Tinggi badan $(\mathrm{m})$ & 142,5 & 171,6 & $155,6 \pm 5,2$ \\
Indeks massa tubuh $\left(\mathrm{kg} / \mathrm{m}^{2}\right)$ & 16,4 & 24,4 & $20,4 \pm 2,2$ \\
\hline
\end{tabular}

\section{HASIL}

Hasil pengukuran antropometrik sampel disajikan pada Tabel 1. Usia seluruh responden termasuk kategori remaja menurut World Health Organization (WHO) yaitu berada pada rentang usia 10-19 tahun. Penghitungan IMT menunjukkan rerata IMT sampel adalah 20,4 \pm $2,02 \mathrm{~kg} / \mathrm{m}^{2}$.

Berdasarkan hasil pada Tabel 2 diketahui bahwa sebanyak $85,4 \%(n=105)$ dari seluruh responden mengalami distorsi citra tubuh. Secara lebih spesifik, sebanyak $94,3 \%(n=99)$ responden yang mengalami distorsi citra tubuh dengan menilai tubuhnya lebih gemuk dari yang sesungguhnya (overestimate), sementara sebesar $5,7 \%$ responden $(\mathrm{n}=6)$ lainnya menilai tubuhnya lebih kurus dari kenyataan (underestimate). Berdasarkan Tabel 2 juga diketahui terdapat $15(12,2 \%)$ responden memiliki risiko rendah gangguan perilaku makan dan $108(87,8 \%)$ responden lainnya termasuk kelompok berisiko tinggi. Sebesar $41,5 \%(\mathrm{n}=51)$ responden sedang atau pernah berusaha menurunkan berat badan dan $58,5 \%(\mathrm{n}=72)$ lainnya mengaku tidak pernah berusaha menurunkan berat badan. Di antara responden yang sedang atau pernah berusaha menurunkan berat badan, hanya $7,8 \%$ responden $(n=4)$ yang melakukan olahraga sebagai upaya penurunan berat badan, sementara $92,2 \%$ $(\mathrm{n}=47)$ lainnya menggunakan metode fad diets.

Berdasarkan Tabel 3, metode fad diets yang paling banyak dilakukan responden adalah dengan mengurangi frekuensi makan (23,8\%); mengonsumsi makanan dengan kombinasi tertentu (19,2\%); menghindari makanan/ minuman tertentu (makanan sumber karbohidrat, makanan manis, makanan berlemak) dan menggantinya dengan suplemen vitamin atau mineral $(15,9 \%)$; mengonsumsi satu jenis makanan tertentu misalnya karbohidrat, protein, atau buah dan sayur saja (9,9\%); melakukan diet yang dipercaya dapat memberi perubahan secara cepat $(7,9 \%)$;
Tabel 2. Prevalensi distorsi citra tubuh, gangguan perilaku makan dan fad diets pada responden

\begin{tabular}{lccc}
\hline Prevalensi responden dengan & n & \% \\
\hline Distorsi citra tubuh & Ya & 105 & 85,4 \\
& Overestimate & 99 & 94,3 \\
& Underestimate & 6 & 5,7 \\
& Tidak & 18 & 14,6 \\
Gangguan perilaku makan & Risiko tinggi & 108 & 87,8 \\
& Risiko rendah & 15 & 12,2 \\
Upaya diet & Ya & 51 & 58,5 \\
& Fad diets & 47 & 92,2 \\
& Bukan fad diets & 4 & 7,8 \\
& Tidak & 72 & 41,5 \\
\hline
\end{tabular}

Tabel 3. Distribusi jenis upaya diet

\begin{tabular}{lcc}
\hline Jenis upaya diet & n & \% \\
\hline $\begin{array}{l}\text { Mengurangi frekuensi makan } \\
\text { (tidak sarapan, tidak makan malam, dsb) }\end{array}$ & 36 & 23,8 \\
$\begin{array}{l}\text { Mengkonsumsi makanan dalam kombinasi } \\
\text { tertentu }\end{array}$ & 29 & 19,2 \\
$\begin{array}{l}\text { Latihan fisik/berolahraga } \\
\text { ( } \geq 3 \text { x seminggu atau 20 menit perhari) }\end{array}$ & 26 & 17,2 \\
$\begin{array}{l}\text { Menghindari makanan/minuman tertentu } \\
\text { (makanan yang mengandung karbohidrat, }\end{array}$ & 24 & 15,9 \\
$\begin{array}{l}\text { makanan manis, makanan berlemak) dan } \\
\text { menggantinya dengan suplemen vitamin }\end{array}$ & & \\
dan mineral & & \\
$\begin{array}{l}\text { Mengkonsumsi satu jenis makanan tertentu } \\
\text { (karbohidrat saja, protein saja, buah dan }\end{array}$ & 15 & 9,9 \\
$\begin{array}{l}\text { sayur saja) } \\
\begin{array}{l}\text { Melakukan diet yang dipercaya dapat } \\
\text { memberi perubahan secara cepat }\end{array}\end{array}$ & 12 \\
$\begin{array}{l}\text { (menurunkan berat badan lebih dari 1kg } \\
\text { dalam seminggu atau perubahan bentuk } \\
\text { tubuh menjadi lebih menarik dengan cepat) }\end{array}$ & & \\
$\begin{array}{l}\text { Mengkonsumsi makanan/minuman yang } \\
\text { dipercaya dapat menghilangkan lemak }\end{array}$ & 7 & 4,6 \\
$\begin{array}{l}\text { (produk pelangsing seperti shaker dengan } \\
\text { formula tertentu, teh pelangsung, minuman } \\
\text { berserat }\end{array}$ & & \\
$\begin{array}{l}\text { Mengkonsumsi pil diet (pil pelangsing, pil } \\
\text { penghilang lemak) }\end{array}$ & 2 & 1,3 \\
\hline
\end{tabular}


Tabel 4. Hubungan distorsi citra tubuh dan gangguan perilaku makan dengan fad diets

\begin{tabular}{|c|c|c|c|c|c|c|c|c|}
\hline \multirow{3}{*}{ Variabel } & & \multicolumn{7}{|c|}{ Fad diets } \\
\hline & & \multicolumn{2}{|c|}{ Ya $(n=47)$} & \multicolumn{2}{|c|}{ Tidak (n=76) } & \multirow[b]{2}{*}{$\mathbf{p}$} & \multirow{2}{*}{ OR (95\% CI) } & \multirow{2}{*}{$\mathbf{r}$} \\
\hline & & $\mathbf{n}$ & $\%$ & n & $\%$ & & & \\
\hline \multirow[t]{2}{*}{ Distorsi citra tubuh } & $\mathrm{Ya}$ & 44 & 41,9 & 61 & 58,1 & 0,032 & 3,607 & 0,190 \\
\hline & Tidak & 3 & 16,7 & 15 & 83,3 & & $(0,984-13,218)$ & \\
\hline \multirow[t]{2}{*}{ Gangguan perilaku makan } & Risiko tinggi & 12 & 80,0 & 3 & 20,0 & 0,000 & 8,343 & 0,321 \\
\hline & Risiko rendah & 35 & 32,4 & 73 & 67,6 & & $(2,221-31,475)$ & \\
\hline
\end{tabular}

Tabel 5. Hubungan distorsi citra tubuh dan gangguan perilaku makan

\begin{tabular}{cccccccc}
\hline & & \multicolumn{5}{c}{ Gangguan perilaku makan } \\
\cline { 3 - 6 } Variabel & & \multicolumn{2}{c}{$\begin{array}{c}\text { Risiko tinggi } \\
(\mathbf{n = 1 5 )}\end{array}$} & \multicolumn{2}{c}{$\begin{array}{c}\text { Risiko rendah } \\
(\mathbf{n = 1 0 8 )}\end{array}$} & \multirow{2}{*}{$\mathbf{p}$} & \multirow{2}{*}{ OR (95\% CI) } \\
\cline { 2 - 6 } & & $\mathbf{n}$ & $\mathbf{9}$ & $\mathbf{n}$ & $\mathbf{\%}$ & & \\
\hline \multirow{2}{*}{ Distorsi citra tubuh } & Ya & 14 & 13,3 & 91 & 86,7 & \multirow{2}{*}{0,310} & 2,615 \\
& Tidak & 1 & 5,6 & 17 & 94,4 & & $(0,322-21,226)$ \\
\hline
\end{tabular}

mengonsumsi makanan atau minuman yang dipercaya bisa menghilangkan lemak (produk pelangsing seperti shaker dengan formula tertentu, slimming tea, atau minuman berserat) $(4,6 \%)$; dan mengonsumsi pil diet (pil pelangsing, pil penghilang lemak) (1,3\%). Meskipun jumlah responden yang menurunkan berat badan dengan latihan fisik atau olahraga selama lebih dari atau sama dengan 3 kali seminggu atau 20 menit per hari cukup banyak (17,2\%), tetapi jumlah ini masih dibawah dari jumlah responden yang melakukan fad diets. Dari seluruh siswi yang melakukan fad diets, diketahui 37 siswi diantaranya melakukan lebih dari satu upaya dalam menurunkan berat badan. Meskipun demikian, sebanyak $56,8 \%$ diantaranya mengombinasikan berolahraga dengan berbagai perubahan pola makan.

Pada saat responden diminta untuk memilih alasan dalam melakukan upaya penurunan berat badan, sebagian besar responden $(38,0 \%)$ mengatakan bahwa mereka ingin mencegah kenaikan berat badan. Sementara itu, sebanyak $27,8 \%$ lainnya mengupayakan penurunan berat badan agar mendapatkan tubuh yang lebih sehat; $22,8 \%$ beralasan agar terlihat lebih menarik dan lebih cantik; $8,9 \%$ karena nasihat dari orangtua, teman, dan lain-lain; 1,3\% karena nasihat dokter; dan 1,3\% lainnya karena alasan lain.

Tabel 4 menampilkan bahwa dari 47 responden yang sedang atau pernah melakukan fad diets, 12 siswi $(25,5 \%)$ diantaranya berisiko tinggi gangguan perilaku makan sedangkan 35 siswi (74,5\%) lainnya berisiko rendah. Pada siswi yang tidak sedang atau pernah melakukan fad diets, hanya 3 siswi (20\%) yang memiliki risiko tinggi terlibat dalam gangguan perilaku makan, sementara 73 siswi $(67,6 \%)$ lainnya memiliki risiko rendah terlibat dalam gangguan perilaku makan. Berdasarkan hasil uji Chi-Square, diketahui terdapat hubungan yang signifikan antara gangguan perilaku makan dengan fad diets $(\mathrm{p}<0,05)$. Nilai OR antar kedua variabel sebesar 8,3 (95\% CI: 2,2-31,5) yang berarti siswi yang berisiko tinggi terlibat dalam gangguan perilaku makan memiliki kemungkinan 8 kali lebih besar untuk berusaha menurunkan berat badannya dengan metode $\mathrm{fad}$ diets. Meski demikian, variansi dengan rentang nilai yang lebar menunjukan bahwa kemungkinan ini dipengaruhi oleh beberapa faktor lain.

Tabel 4 juga menunjukkan bahwa dari 47 siswi yang sedang atau pernah melakukan fad diets, 44 siswi (93,6\%) diantaranya memiliki distorsi citra tubuh. Sementara itu, dari 76 siswi yang tidak sedang atau pernah melakukan $\mathrm{fad}$ diets, 61 siswi (80,3\%) diantaranya juga memiliki distorsi citra tubuh. Hasil uji tabulasi silang menunjukkan adanya hubungan yang signifikan secara statistik antara distorsi citra tubuh dengan fad diets. Siswi dengan distorsi citra tubuh memiliki kemungkinan 3,6 kali lebih besar untuk menurunkan berat badan dengan metode fad diets.

Tabel 5 menunjukkan bahwa dari 15 responden dengan risiko tinggi gangguan perilaku makan, 14 
orang $(93,3 \%)$ diantaranya memiliki distorsi citra tubuh. Sementara itu, dari 108 siswi yang memiliki risiko rendah terlibat dalam gangguan perilaku makan, 91 siswi $(84,2 \%)$ diantaranya diketahui juga memiliki distorsi citra tubuh. Meskipun berdasarkan hasil analisis tabulasi silang tidak ditemukan hubungan yang signifikan, secara statistik antara distorsi citra tubuh dengan gangguan perilaku makan menunjukan bahwa siswi SMA Negeri 8 Yogyakarta dengan distorsi citra tubuh memiliki risiko 2,6 kali lebih besar (95\% CI: 0,3-21,2) untuk terlibat dalam gangguan perilaku makan dibandingkan dengan siswi yang tidak memiliki distorsi citra tubuh.

\section{BAHASAN}

Hasil penelitian ini menunjukan adanya hubungan yang signifikan $(\mathrm{p}<0,05)$ antara gangguan perilaku makan dengan fad diets serta distorsi citra tubuh dengan fad diets, tetapi tidak ditemukan hubungan yang signifikan antara distorsi citra tubuh dengan perilaku makan. Meskipun demikian, prevalensi siswi yang memiliki distorsi citra tubuh dan berisiko tinggi terlibat dalam gangguan perilaku makan lebih tinggi (13,3\%) dibandingkan prevalensi siswi tanpa distorsi citra tubuh (5,6\%). Demikian halnya dengan prevalensi siswi dengan distorsi citra tubuh yang melakukan fad diets lebih tinggi $(41,9 \%)$ dibandingkan siswi tanpa distorsi citra tubuh $(16,7 \%)$.

Remaja putri merasa identitas mereka ditentukan oleh bentuk tubuh dan bentuk tubuh yang gemuk bukanlah bentuk tubuh yang mereka inginkan. Dengan memiliki tubuh yang ramping, mereka akan merasa lebih percaya diri, populer, serta lebih mudah mendapat pekerjaan dan pasangan $(31,32)$. Remaja putri merasa bahwa daya tarik mereka akan meningkat apabila mereka memiliki tubuh yang kurus, sehingga mereka akan sangat memperhatikan dan menjaga berat badan (9). Secara internal, jenis kelamin perempuan, ras tertentu, usia remaja, dan citra tubuh yang negatif dapat meningkatkan risiko seseorang untuk terjebak ke dalam gangguan perilaku makan (22,31-34). Sementara dari faktor eksternal, tekanan dari keluarga, paparan media massa, lingkungan pertemanan, faktor ekonomi, dan budaya setempat dapat mempengaruhi kemungkinan seseorang untuk mengalami gangguan perilaku makan $(19,22,35,36)$.
Berdasarkan penelitian ini juga diketahui bahwa sekalipun secara statistik distorsi citra tubuh tidak memiliki hubungan yang siginifikan dengan gangguan perilaku makan, tetapi prevalensi responden dengan distorsi citra tubuh yang terlibat dalam gangguan perilaku makan lebih besar daripada responden tanpa distorsi citra tubuh yang berisiko tinggi terlibat dalam gangguan perilaku makan. Diketahui pula remaja dengan distorsi citra tubuh memiliki kemungkinan 2,6 kali lebih besar untuk terjebak dalam gangguan perilaku makan dibandingkan remaja tanpa distorsi tubuh. Hasil penelitian ini sejalan dengan studi terdahulu $(23,37)$, yaitu remaja yang tidak merasa puas dengan bentuk tubuhnya, tidak hanya terjadi pada remaja yang memang memiliki tubuh yang gemuk, tetapi juga remaja dengan status gizi kurus memiliki kecenderungan yang lebih besar untuk terlibat dalam perilaku makan yang menyimpang.

Remaja putri rentan untuk terjebak kedalam gangguan perilaku makan yang menyimpang karena para remaja ini sangat memperhatikan apa yang mereka makan untuk mencapai bentuk tubuh yang diinginkan. Kebiasaan makan seseorang tidak banyak dipengaruhi oleh pengetahuan seseorang akan makanan itu sendiri, tetapi lebih disebabkan oleh kepedulian mereka yang tinggi akan bentuk tubuh (32). Para remaja dengan berat badan normal yang merasa dirinya gemuk, akan berkeinginan untuk mengubah penampilannya salah satunya dengan mengubah perilaku makan (38). Mereka seringkali memperhitungkan berapa besar kalori yang mereka konsumsi dan membatasi konsumsi makanan mereka apabila dirasa sudah melebihi kebutuhan, meskipun sebenarnya belum tentu besar kalori yang mereka konsumsi memang terbukti melebihi kebutuhan kalori harian (6).

Menurut hasil analisis hubungan antara gangguan perilaku makan dengan fad diets, dapat dilihat bahwa ada hubungan yang bermakna secara statistik $(\mathrm{p}<0,05)$ antara kedua variabel tersebut. Meskipun korelasinya lemah, tetapi semakin besar risiko seseorang untuk terlibat dalam gangguan perilaku makan, semakin besar pula kemungkinan orang tersebut untuk melakukan $\mathrm{fad}$ diets. Siswi yang berisiko tinggi memiliki gangguan perilaku makan memiliki kecenderungan 8 kali lebih besar untuk menurunkan berat badannya dengan metode 
fad diets. Prevalensi siswi yang berisiko tinggi terlibat dalam perilaku makan dan menjalankan fad diets (80\%) juga lebih besar daripada siswi dengan risiko rendah gangguan perilaku makan (32,4\%). Hal ini disebabkan oleh sebagian besar jenis upaya fad diets berkaitan langsung dengan perubahan perilaku makan.

American Heart Association mendefinisikan fad diets sebagai upaya penurunan berat badan yang menekankan pada pembatasan jenis dan jumlah makanan tertentu dengan menu yang tidak bervariasi serta penggunaan obat atau suplemen diet dengan peningkatan aktivitas fisik yang minimal. Definisi ini terbukti melalui hasil penelitian ini yang menunjukkan bahwa jenis upaya fad diets yang paling banyak digunakan para siswi adalah mengurangi frekuensi makan (23,8\%), menghindari jenis makanan tertentu (19,2\%), dan disusul oleh berolahraga selama lebih dari 3 kali seminggu selama 20 menit $(17,2 \%)$. Hasil penelitian ini sesuai dengan penelitian yang mengemukakan bahwa pembatasan makanan berkaitan langsung dengan upaya pengurangan konsumsi makanan agar terjadi penurunan berat badan $(38,39)$. Pemilihan upaya olahraga yang bukan menjadi pilihan utama pada responden didukung oleh penelitian terdahulu yang bertujuan untuk mengetahui faktor-faktor yang berhubungan dengan perilaku diet pada remaja, diketahui belum ada hubungan yang signifikan antara gangguan perilaku makan pada remaja dengan perilaku diet yang sehat seperti olahraga. Meskipun demikian, terdapat kecenderungan bagi para remaja dengan gangguan perilaku makan untuk tidak menurunkan berat badannya dengan olahraga secara teratur.

Hasil analisis menemukan adanya hubungan yang bermakna secara statistik antara distorsi citra tubuh dengan fad diets, prevalensi siswi dengan distorsi citra tubuh yang berupaya menurunkan berat badannya dengan metode fad diets $(41,9 \%)$ lebih besar daripada siswi tanpa distorsi citra tubuh (16,7\%). Hal ini disebabkan oleh kebanyakan remaja sudah memiliki bentuk tubuh yang sudah normal, tetapi mereka tetap merasa bahwa tubuhnya gemuk dan pada akhirnya cenderung berusaha untuk menurunkan berat badannya dengan diet (22). Hal ini terjadi kemungkinan karena bukan status kegemukan yang mendorong seseorang untuk menurunkan berat badan, melainkan persepsi orang itu sendiri yang memotivasi untuk berdiet (40). Semakin positif gambaran tubuh seseorang, akan semakin rendah intensitas mereka untuk berdiet. Sekalipun bentuk tubuh seseorang sudah termasuk proporsional, tetapi apabila mereka merasa tidak ideal, mereka akan tetap berusaha menurunkan berat badannya $(20,24,41)$.

Hasil penelitian ini sejalan dengan penelitianpenelitian yang mengemukakan bahwa remaja yang mengasumsikan dirinya gemuk akan cenderung untuk mengontrol berat badannya $(15,22,42)$. Hal ini disebabkan oleh perilaku diet seseorang tidak hanya dipengaruhi oleh distorsi citra tubuh. Pengaruh lingkungan pertemanan, tingkat depresi, tingkat kepercayaan diri, dan paparan media massa merupakan beberapa faktor lain yang dapat mempengaruhi cara seseorang dalam menurunkan berat badan $(16,17,22)$. Salah satu kelemahan penelitian ini bahwa variabel distorsi citra tubuh belum dibedakan menurut jenisnya (overestimate dan underestimate) sedangkan terdapat kemungkinan terjadi kecenderungan yang berbeda antara remaja yang overestimate dan underestimate. Oleh karena itu, perlu dilakukan penelitian lebih jauh yang membedakan hubungan jenis distorsi dengan perilaku makan dan perilaku diet seseorang.

Kebanyakan studi terkait distorsi citra tubuh, perilaku makan, dan perilaku diet dilakukan pada sampel remaja putri secara umum baik yang memiliki IMT kurang, normal maupun lebih $(8,19-23)$ tidak spesifik kepada satu kelompok status gizi tertentu saja. Dengan demikian, diharapkan penelitian ini dapat memberikan gambaran tentang diet yang banyak dilakukan oleh para remaja putri sekarang ini dan faktor-faktor yang berkaitan. Menurut angka kecukupan gizi (AKG) tahun 2013 kebutuhan energi rata-rata remaja putri adalah sebesar $2.575 \mathrm{kkal}$ dengan protein sebesar $69 \mathrm{~g}$, lemak sebesar 86 g, dan karbohirat sebesar 354 g. Berdasarkan berbagai penelitian, diketahui bahwa nilai gizi dari jenis-jenis fad diets ini tidaklah mencukupi kebutuhan para remaja putri. Dengan demikian, penting dilakukan upaya memberikan pemahaman yang benar tentang kebutuhan energi yang sesuai untuk kebutuhan remaja putri, serta cara dan sumber pemenuhan kebutuhan energi yang tepat dan sehat. Pengetahuan tersebut akan dapat menekan perilaku makan (diet) yang tidak tepat termasuk fad diet. 


\section{SIMPULAN DAN SARAN}

Sebanyak 85,3\% siswi SMA Negeri 8 Yogyakarta merasa dirinya gemuk meskipun status gizinya tergolong normal. Diet yang dilakukan para remaja putri ini sebagian besar berupa fad diets. Bentuk upaya yang paling sering dilakukan adalah dengan melewatkan waktu makan tertentu. Meskipun demikian, tidak ditemukan hubungan yang signifikan antara distorsi citra tubuh pada siswi SMA Negeri 8 Yogyakarta dengan fad diets dan gangguan perilaku makan. Perlu dilakukan upaya memberikan pemahaman yang benar tentang kebutuhan energi yang sesuai untuk kebutuhan remaja putri, serta cara dan sumber pemenuhan kebutuhan energi yang tepat dan sehat.

\section{UCAPAN TERIMA KASIH}

Penulis mengucapkan terimakasih kepada Perdana Samekto, M.Sc yang telah memberikan saran-saran dalam penelitian ini.

\section{RUJUKAN}

1. Brown FL, Slaughter V. Normal body, beautiful body: discrepant perceptions reveal a pervasive "thin ideal" from childhood to adulthood. Body Image 2011;8:119-25.

2. Kay S. The psychology and anthropometry of body image. In: Norton K, Olds T (Eds.). Anthropometrica, a textbook of body measurement for sports and health courses. Sydney: UNSW Press Book; 2001.

3. Tiggemann M. Media influences on body image development. In: Cash T, Pruzinskky T (Eds.). Body image, a handbook of theory, research, and clinical practise. NY: The Guilford Press; 2002.

4. Hargreaves DA, Tiggemann M. Idealized media images and adolescent body image: "comparing" boys and girls. Body Image 2004;1(4): 51-61.

5. Yamamiya Y, Cash TF, Melnyk SE, Posavac HD, Posavac SS. Women's exposure to thin-and-beautiful media images: Body image effects of media-ideal internalization and impact-reduction interventions. Body Image 2005;2:7480 .

6. Evans EH, Tovée MJ, Boothroyd LG, Drewett RF. Body dissatisfaction and disordered eating attitudes in 7- to 11year-old girls: Testing a sociocultural model. Body Image 2013;10:8-15.

7. Dittmar H. Consumer culture, identity and well-being: the search for the good life and the body perfect. London: Psychology Press; 2007.
8. Bibiloni M del M, Pich J, Pons A, Tur J. Body image and eating patterns among adolescents. BMC Public Health 2013;13:1104.

9. Xie B, Chou C, Spruijt-metz D, Reynolds K, Clark F, Palmer $\mathrm{PH}$, et al. Weight perception and weight-related sociocultural and behavioral factors in Chinese adolescents. Prev Med 2006;42:229-34.

10. Xu X, Mellor D, Kiehne M, Ricciardelli LA, McCabe MP, Xu Y. Body dissatisfaction, engagement in body change behaviors and sociocultural influences on body image among Chinese adolescents. Body Image 2010; 7(2):156-64.

11. Helfert $S$, Warschburger P. A prospective study on the impact of peer and parental pressure on body dissatisfaction in adolescent girls and boys. Body Image 2011;8:101-9.

12. Dewanto VC. Hubungan antara citra tubuh dengan depresi pada remaja perempuan di SMA Stella Duce. [Skripsi]. Yogyakarta: Fakultas Kedokteran Universitas Gadjah Mada; 2013.

13. Maitri AK. Hubungan citra tubuh dan konsumsi lemak siswi SMAN 3 Yogyakarta [Skripsi]. Yogyakarta: Universitas Gadjah Mada; 2007.

14. Wahyuningtyas DS. Hubungan antara IMT dan citra tubuh pada siswa SMAN 1 Sleman [Skripsi]. Yogyakarta: Universitas Gadjah Mada; 2009.

15. Liechty JM. Body image distortion and three types of weight loss behaviors among nonoverweight girls in the United States. J Adolesc Health 2010;47:176-82.

16. Hana S. Harga diri, body image dan fad diets pada siswi SMAN 6 Yogyakarta [Skripsi]. Yogyakarta: Universitas Gadjah Mada; 2014.

17. Rafiqa H. Depresi, media dan teman sebaya pada fad diets siswi SMAN 6 Yogyakarta [Skripsi]. Yogyakarta: Universitas Gadjah Mada; 2014.

18. Almatsier S. Prinsip dasar ilmu gizi. Jakarta: Gramedia Pustaka Utama; 2004.

19. Fairburn CG, Harrison PJ. Eating disorders. Lancet 2003;361:407-16.

20. Chang F, Lee C, Chen P, Chiu C, Pan Y, Huang T. Eating behaviors association of thin-ideal media exposure, body dissatisfaction and disordered eating behaviors among adolescents in Taiwan. Eat Behav 2013;14:382-5.

21. Chung AE, Perrin EM, Skinner AC. Accuracy of child and adolescent weight perceptions and their relationships to dieting and exercise behaviors : a NHANES Study. Acad Pediatr 2013;13:371-8.

22. Lefan PN. Hubungan antara faktor lingkungan, citra tubuh dan diet penurunan berat badan pada remaja putri di SMA di Distrik Abepura Kota Jayapura [Tesis]. Yogyakarta: Universitas Gadjah Mada; 2012.

23. Neumark-sztainer D, Hannan PJ. Weight-related behaviors among adolescent girls and boys. Arch Pediatric Adolesc Med 2000;154:569-77. 
24. Rahayu A. Hubungan antara citra tubuh dengan perilaku makan remaja di sma wilayah kota banjarmasin provinsi kalimantan Selatan [Tesis]. Yogyakarta: Universitas Gadjah Mada; 2012.

25. Martin Ginis K, McEwan D, Josse AR, Phillips SM. Body image change in obese and overweight women enrolled in a weight-loss intervention: The importance of perceived versus actual physical changes. Body Image 2012;9:311-7.

26. de Onis M, Onyango AW, Borghi E, Siyam A, Nishida C, Siekmann J. Development of a WHO growth reference for school-aged children and adolescents. Bulletin of the World Health Organization 2007;85:660-7.

27. Lemeshow S, Lwanga SK. Sample size determination in health studies. Geneva: World Health Organization; 1991.

28. Gardner RM, Jappe LM, Gardner L. Development and validation of a new figural drawing scale for body-image assessment: the BIAS-BD. J Clin Psych 2009;65:113-22.

29. Stunkard A, Sorenson T, Schlusinger E. Use of the Danish Adoption Registry for the study of obesity and thinness. Res Publ Assoc Res Nerv Ment Dis 1983;60:115-20.

30. Garner DM, Olmsted MP, BohrY, Garfinkel PE. The eating attitude test: Psycometric features and clinical correlates. Psychol Med 1982;12: 871-8.

31. Helfert S, Warschburger P. A prospective study on the impact of peer and parental pressure on body dissatisfaction in adolescent girls and boys. Body Image 2011;8:101-9.

32. Tejoyuwono AA. Persepsi mahasiswa program studi S1 Gizi Kesehatan Fakultas Kedokteran Universitas Gadjah Mada terhadap citra ahli gizi. Jurnal Gizi Klinik Indonesia 2011;8(1):42-9.

33. Lai Yeung WT. Gender perspectives on adolescent eating behaviors: a study on the eating attitudes and behaviors of junior secondary students in Hong Kong. J Nutr Edu Behav 2010;42(4):250-8.
34. Li KK, Concepcion RY, Lee H, Cardinal BJ, Ebbeck V, Woekel E, et al. An examination of sex differences in relation to the eating habits and nutrient intakes of university students. J Nutr Edu Behav 2012;44(3):246-50.

35. Zoletić E, Duraković-Belko E. Body image distortion, perfectionism and eating disorder symptoms in risk group of female ballet dancers and models and in control group of female students. Psychiatr Danub 2009;21(3):302-9.

36. Bruening M, Eisenberg M, MacLehose R, Nanney MS, Story M, Neumark-Sztainer D. Relationship between adolescents' and their friends' eating behaviors: breakfast, fruit, vegetable, whole-grain, and dairy intake. J Acad Nutr Diet 2012;112(10):1608-13.

37. Hargreaves DA, Tiggemann M. Idealized media images and adolescent body image: "comparing" boys and girls. Body Image 2004;1(4):351-61.

38. Habibah N. Hubungan paparan Korean Wave melalui media informasi dengan body image dan risiko eating disorder pada remaja putri SMA Kota Yoygakarta [Skripsi]. Yogyakarta: Universitas Gadjah Mada; 2014.

39. Flament MF, Hill EM, Buchholz A, Henderson K, Tasca GA, Goldfield G. Internalization of the thin and muscular body ideal and disordered eating in adolescence: the mediation effects of body esteem. Body Image 2011; 9(1):68-75.

40. Elfhag K, Morey LC. Personality traits and eating behavior in the obese: poor self-control in emotional and external eating but personality assets in restrained eating. Eat Behav 2008;9(3):285-93.

41. van Strien T, Peter Herman C, Verheijden MW. Eating style, overeating and weight gain. A prospective 2-year follow-up study in a representative Dutch sample. Appetite 2012;59(3):782-9.

42. Klesse AK, Goukens C, Geyskens K, de Ruyter K. Repeated exposure to the thin ideal and implications for the self: two weight loss program studies. Int J Res Mark 2012;29(4):35562. 